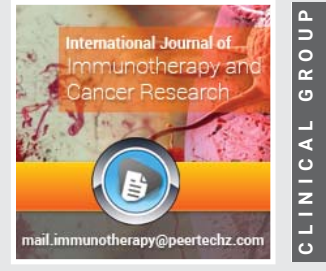

Short Communication

\section{New insights on assessing cancer risk of exposure to carcinogens from tobacco smoke inhalation}

\author{
Samera Hussein Hamad* \\ Curriculum in Toxicology and Environmental Medicine, School of Medicine, University of North \\ Carolina at Chapel Hill, USA
}

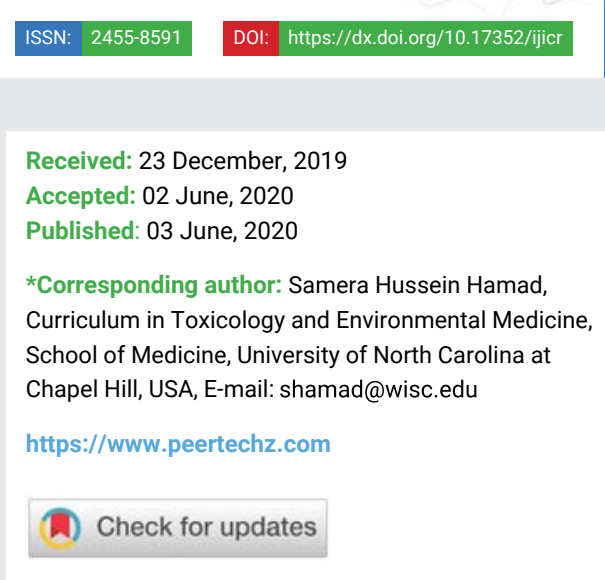

Tobacco products is still the leading cause of deaths worldwide. $80 \%$ of lung cancer is attributed to tobacco smoking [1-3]. It has been found that the exposure to tobacco smoke is the primary etiologic factor responsible for lung cancer; and that the decline in the incidence and the mortality of lung cancer is associated with the decline in smoking $[3,4]$. At the same time, the use of e-cigarette (e-cig) starts to arise rapidly; almost all major tobacco manufacturers are now marketing e-cigarette [2]. However, e-cigarette (e-cig), another tobacco product that was considered for regulation by the U.S. Food and Drug Administration (FDA), is also another tool that delivers toxicants to e-cig users. Several publications demonstrated the levels of carcinogens found in e-cig aerosols including formaldehyde, acetaldehydes, and acrolein that are formed from thermal decomposition of vegetable glycerin (VG) and propylene glycol (PG), the e-liquid of e-cig [5,6]. Other carcinogens including tobacco specific nitrosamines (TSNAs) that are formed from tobacco alkaloids including nicotine and make biological changes [7,8]. After exposure, these carcinogens can damage cells by binding to DNA and forming carcinogen-DNA adducts which interfere with DNA replication and can lead to mutations that contribute to the initiation and development of cancerous tumors [8, 9]. However, the carcinogenic effect of these compounds depends on their reactivity and the time of exposure to these carcinogens (the accumulation effect). In order to better predict whether a specific level of exposure to carcinogen can make biological changes or not, we need to precisely estimate the exposure level. One fast and cost-effective approach is the use of computational modeling of health risk $[10,11]$. Several agencies including U.S. Environmental Protection Agency
(US EPA) through its Integrated Risk Information System (IRIS), and the Agency for Toxic Substances and Disease Registry (ATSDR), have already established parameters such as reference exposure levels, minimal risk levels and cancer potency factors. These reference doses can aid in estimation of health risk and toxicity thresholds associated with known exposures to individual carcinogen in tobacco smoke. In fact, this approach has been explored previously using the total concentration of toxic compounds in mainstream smoke [1214]. Although informative, these studies may not provide an accurate risk profile because human behavior and biology modify the actual exposure to carcinogens. In our previous studies of soil contaminants, we demonstrated that the total concentration of toxicants overestimates the risk of exposure, and that the bioavailable fraction of toxicants should be considered for risk assessment [10]. Currently there is a very limited data regarding the inhaled fraction of toxicants, and no data regarding the bioavailability of the inhaled fraction of toxicants. Additionally, very little modeling and risk assessment studies have integrated human behavior into the risk paradigm [15], most studies are relying on standardized smoking machine regimens to generate smoke; therefore, a more accurate approach should incorporate the inhaled fraction of carcinogens and human smoking behavior. Our current work is to establish a new insights on assessing the health risk, especially cancer risk of exposure to carcinogens from tobacco smoke inhalation taking into consideration the actual inhaled and the bioavailable faction of the inhaled carcinogens based on the actual human smoking or vaping behaviors to better estimate the cancer risk of exposure to carcinogens from tobacco smoke. 


\section{References}

1. Society AC (2019) Cancer Facts and Figures 2019. American Cancer Society Inc. Link: https://bit.ly/2zQmoOA

2. Adam S (2016) E-cigarette manufacturers say new regulations will devastate the industry. Forbes. Link: https://bit.ly/2MjONc2

3. Siegel RL, Miller KD, Jemal A (2019) Cancer statistics, 2019. CA Cancer J Clin 69: 7-34. Link: https://bit.ly/2Xno0BZ

4. Giovino GA (2002) Epidemiology of tobacco use in the United States. Oncogene 21: 7326-7340. Link: https://go.nature.com/36QUOGM

5. Kosmider L, Sobczak A, Fik M, Knysak J, Zaciera M, et al. (2014) Carbonyl compounds in electronic cigarette vapors: effects of nicotine solvent and battery output voltage. Nicotine Tob Res 16: 1319-1326. Link: https://bit.ly/2Ml8ws3

6. Jensen RP, Luo W, Pankow JF, Strongin RM, Peyton DH (2015) Hidden formaldehyde in e-cigarette aerosols. $\mathrm{N}$ Engl $\mathrm{J}$ Med 372: 392-394. Link: https://bit.ly/2Mi4vVn

7. Yalcin E, de la Monte S (2016) Tobacco nitrosamines as culprits in disease: mechanisms reviewed. J Physiol Biochem 72: 107-120. Link: https://bit.ly/3eE9fRd

8. Lee HW, Park SH, Weng MW, Wang HT, Huang WC, et al. (2018) E-cigarette smoke damages DNA and reduces repair activity in mouse lung, heart, and bladder as well as in human lung and bladder cells. Proc Natl Acad Sci USA. 115: E1560-e1569. Link: https://bit.ly/3gM2T40
9. Zhong W, Que Hee SS (2004) Formaldehyde-induced DNA adducts as biomarkers of in vitro human nasal epithelial cell exposure to formaldehyde. Mutat Res 563: 13-24. Link: https://bit.ly/2XPLT4d

10. Hamad SH, Schauer JJ, Shafer MM, Al-Rheem EA, Skaar PS, et al. (2014) Risk assessment of total and bioavailable potentially toxic elements (PTEs) in urban soils of Baghdad-Iraq. Sci Total Environ. 494-495: 39-48. Link: https://bit.ly/3eKSCTN

11. Samera Hamad DG, Jongbae Heo (2016) Evaluation of health risk associated with fireworks activity at Central London. Air Quality, Atmosphere \& Health 9. Link: https://bit.ly/3006LZe

12. Fowles J, Dybing E (2003) Application of toxicological risk assessment principles to the chemical constituents of cigarette smoke. Tob Control 12 424-430. Link: https://bit.ly/2Xt6xsd

13. Ayo-Yusuf OA, Connolly GN (2011) Applying toxicological risk assessment principles to constituents of smokeless tobacco products: implications for product regulation. Tob Control 20: 53-57. Link: https://bit.ly/2XoqKz5

14. Xie J, Marano KM, Wilson CL, Liu H, Gan H, et al. (2012) A probabilistic risk assessment approach used to prioritize chemical constituents in mainstream smoke of cigarettes sold in China. Regul Toxicol Pharmacol 62: 355-362. Link: https://bit.ly/3cj6NOY

15. Watanabe KH, Djordjevic MV, Stellman SD, Toccalino PL, Austin DF, et al (2009) Incremental lifetime cancer risks computed for benzo[a]pyrene and two tobacco-specific $\mathrm{N}$-nitrosamines in mainstream cigarette smoke compared with lung cancer risks derived from epidemiologic data. Regul Toxicol Pharmacol 55: 123-133. Link: https://bit.ly/2XUUjHJ

\section{Discever a bigger lepact and Vistillity of your article patieation with} Peertechz Publications

\section{HighNohts}

- Spnatsry putilinef of Oincio

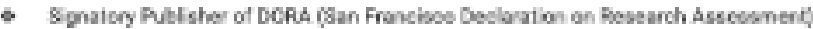

- Articles archieed in morlds renowned sarvice providers wash as Portica, CNel. MGeis,

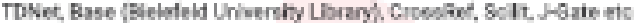

- Journwie indeard in ICU.E, SHEBPMACME0, Google Seholar eto.

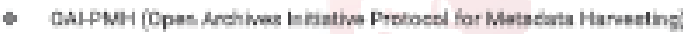

- Dedicated Edhorisl Baard foe every joumd

- Asturaie and rapid peereview proctss

- hereosad etotions of putishad articles trough srometiens

- Reduoed tmelhe for article pibllostion

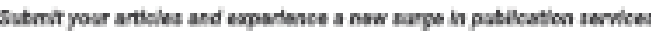

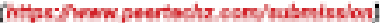

Copyright: (c) 2020 Hamad SH. This is an open-access article distributed under the terms of the Creative Commons Attribution License, which permits unrestricted use, distribution, and reproduction in any medium, provided the original author and source are credited.

Citation: Hamad SH (2020) New insights on assessing cancer risk of exposure to carcinogens from tobacco smoke inhalation. Int J Immunother Cancer Res 6(1): 014-015. DOI: https://dx.doi.org/10.17352/2455-8591.000023 